\title{
Evaluation of the benefit with the use of the sound amplification inchildren and teenagers
}

\section{Avaliação do benefício com o uso da amplificação sonora em crianças e adolescentes}

\author{
Nilvia Herondina Soares Aurélio', Enma Mariángel Ortiz Torres², Aline da Silva Lopes³, Maristela Julio Costa4. \\ 1) Master in Disorders of Human Communication by the Universidade Federal de Santa Maria. Speech Therapist. \\ 2) Master in Disorders of Human Communication by the Universidade Federal de Santa Maria. Speech Therapist. \\ 3) Master in Disorders of Human Communication by the Universidade Federal de Santa Maria. Speech Therapist from the Universidade Federal de Pelotas. \\ 4) Ph.D. in Science from the Disorders of Human Communication by the Universidade Federal de São Paulo. Speech Therapist; Associate Professor from the Phonoaudiology \\ Departament from Universidade Federal de Santa Maria. \\ Institution: Departament of Phonoaudiology by the Universidade Federal de Santa Maria \\ Santa Maria / RS - Brazil. \\ Mailling Adress: Enma Mariángel Ortiz Torres - Avenida Presidente Vargas, 1720 - Apto. 302 - Centro - Santa Maria / RS - Brazil - Zip Code: 97015-510 - Telephone: \\ (+55 55) 3304-1361 - E-mail: emmita_06@hotmail.com \\ Article received in July $8^{\text {th }}$ of 2011 . Article approved in October $12^{\text {th }}$ of 2011
}

\section{SUMMARY}

Objective: Evaluate the proportionate benefit by the sound amplification in children and teenagers attended by the program of hearing health attention by the Federal University of Santa Maria (UFSM).

Method: Participated from these study 63 individuals with age between 3 and 14 years and their family. For the evaluate the benefit proportionate by the sound amplification was applied the Infant Toddler Meaningful Auditory Integration Scale (ITMAIS), for children with less than 4 years old; the Meaningful Auditory Integration Scale (MAIS), for infants from 4 to 7 years and the questionnaire of evaluation from the benefit in infants and young, for the individuals from 8 to 14 years.

Results: Only one individual could be evaluated through the MAIS scale, and the average punctuation found in the evaluation of the hearing behaviors was of 19,9. Were evaluated 52 individuals through the questionnaire of evaluation of benefit in infants and teenagers, and the positive answers related to the benefit proportionate by the prosthesis in different situations were the most found in all items.

Conclusions: Was verified the benefit proportionate by the sound amplification, in different situations of daily life, such as from the patient's perspective as from his family. In some cases, where were found little or none benefit, there were influence of others clinical alterations, besides the hearing loss, influencing the effective use of the hearing aids.

Keywords: hearing, hearing loss, auxiliary from hearing, children, questionnaire.
RESUMO

Objetivo: Avaliar o benefício proporcionado pela amplificação sonora em crianças e adolescentes atendidos pelo programa de atenção à saúde auditiva da Universidade Federal de Santa Maria (UFSM).

Método: Participaram deste estudo 63 indivíduos com idade entre 03 e 14 anos e seus familiares. Para avaliar o benefício proporcionado pela amplificação sonora foi aplicada a Escala de Integração Auditiva Significativa para Crianças Pequenas (IT-MAIS), para as crianças com menos de 04 anos; a Escala de Integração Auditiva Significativa (MAIS), para as crianças de 04 a 07 anos e o questionário de avaliação do benefício em crianças e jovens, para os indivíduos de 08 a 14 anos.

Resultados: Somente um indivíduo pôde ser avaliado através da escala IT-MAIS, o qual obteve a pontuação 0 (zero), indicando ausência dos comportamentos auditivos avaliados. Dez indivíduos foram avaliados através da escala MAIS, sendo que a pontuação média encontrada na avaliação dos comportamentos auditivos foi de 19,9. Foram avaliados 52 indivíduos através do questionário de avaliação do benefício em crianças e jovens, sendo que as respostas positivas relacionadas ao benefício proporcionado pelas próteses em diferentes situações foram as mais encontradas em todos os itens.

Conclusão: Foi verificado benefício proporcionado pela amplificação sonora, em diferentes situações da vida diária, tanto pela ótica do paciente, quanto de sua família. Em alguns casos, onde foi encontrado pouco ou nenhum benefício, houve influência de outras alterações clínicas, além da perda auditiva, influenciando no uso efetivo das próteses auditivas. Palavras-chave: audição, perda auditiva, auxiliares de audição, criança, questionários. 


\section{INTRODUCTION}

The hearing loss, independently from degree, can take to a series of perceptual impairments and changes in the speech, damaging the communication from the individual and can cause secondary deficiencies involving the cognitive, emotional, social and educational aspects (1).

To minimize these commitments, is necessary the diagnosis and the efficient early intervention, with the indication and adaptation from the adequate hearing aids, also as specialized therapeutic accompaniment (2).

The benefits and limitations from the abilities of hearing of the children using hearing aids are evaluated by the phonoaudiologist, in the final stage from the process of adaptation from the hearing aids. Is verified, though, which are the effects of amplification in the quality of life from the child (3)

To verify these benefits, the phonoaudiologist can use procedures to observe the behavior of that child in respond to the amplified signal provided by the hearing aid, quantify the behaviors responses using the amplification by means of functional gain and from tests of speech perception (direct measures); like also, analyze the indirect measures from the performances obtained in interviews with parents, caregivers and/or educators by means of a questionnaire developed for such purpose (3).

With the purpose to verify the benefit according to the sound amplification in children with less than 4 years and from 4 to 7 years, respectively, was developed the Infant-toddler Meaningful Auditory Integration (IT-MAIS) and the Meaningful Auditory Integration Scale (MAIS). These scales approach information related to the frequency that the child shows significant hearing behaviors in the day-to-day.

To research the benefit provided by the amplification in patients with ages between 7 and 14 years, Boscolo et al. (2006) developed a questionnaire of self-evaluation, which contain closed questions and illustrative engravings, that aim to know the improvement of performance provided by the amplification in the home environment, at school and in the social living in children and teenagers (8).

Such instruments allow the audiologist to investigate the perception of the patient and from the family about the difficulties of communication, monitoring its progress and locate their hearing needs outside from the standard audiometric battery (9).

With base in these purposes, the objective of this study was to evaluate the benefit provided by the use of sound amplification by means of instruments of selfevaluation in children and teenagers attended by the program of attention to the hearing health from Universidade Federal de Santa Maria (UFSM).

\section{MethODS}

The present study was performed at Laboratory of Hearing Aids (LHA) from the Service of Phonoaudiologic Attendance (SPA) from Universidade Federal de Santa Maria (UFSM), in the period between April and August of 2009 .

This research is linked to the project "Research and Data Basis in Hearing Health", registered at the office Projects from the Center of Sciences of Health under the number: 019731 and approved by the Committee of Ethics in Research (CER) from UFSM in 12/05/2006, protocol $n^{\circ}$ 23081.0.016862/2006-09.

Participated from this study, individuals with hearing loss, prothetizades in the Laboratory of Hearing Aids from UFSM by means of a program of attention to hearing health of this institution. This program is current since the year 2005 and attend in the average complexity the municipalities from the Midwest macro-region from the state of Rio Grande do Sul.

Only were evaluated the individuals which parents or responsible agreed with the performance from the needed procedures for the execution of the research and signed the Term of Consent Free and Clarified, after had received the clarification about the objective and methodology from the proposed study.

To do part of the research, the criteria of inclusion established were: have age between 3 to 14 years and a minimum time of three months of use of the amplification, because the clinical experience have showed that this is a reasonable time for the adaptation to hearing aid, being possible verify the real results of the intervention, since the benefits arising from the use of the amplification do not emerge immediately (10).

The individuals were evaluated during a follow-up of the process of adaptation of hearing aids, where a member of a family or responsible by the child or teenager was present. This session, was checked the technical conditions of the hearing aids and a interview was performed containing aspects like effectiveness and the frequency of use of the hearing aids by the child and teenager; complaints and difficulties related to the use of the hearing aids; the development and school performance of the patient; the 
performance of an phonoaudiologicaccompaniment, among others.

The benefit obtained with the use of the sound amplification was researched through application of questionnaires of self-evaluation compatible with the age of the patients.

For the verification of the benefit regarding the sound amplification in children until 4 years old, was used the scale of significant hearing integration for small children, the IT-MAIS-Infant-toddler Meaningful Auditory Integration (Annex 1). This scale researches spontaneous hearing behaviors of children in situations of daily life, through examples in three different areas of development from the hearing abilities. This three areas include changes in the vocalization associate with the use of the device, alert for environmental sounds and attribution of meaning to the sound $(5,6)$.

For children aged between 4 and 7 years, was applied the scale of significant hearing integration, the MAIS - Meaningful Auditory Integration Scale (Annex 2). This scale contains ten close questions that evaluate the connection of the child with the hearing aid; the capacity of alert for the sounds and the capacity of extract the meaning from auditory phenomena $(4,7)$.
These scales were developed to evaluate children with hearing loss of profound degree and are scored trough information from the family or responsible by the children. For each question, there was the possibility of 5 answers, and each question was scored by the frequency of occurrence from the behavior that varies from 0 ("never showed such behavior") to 4 ("always showed such behavior"). The total possibility of score in the scales MAIS and IT-MAIS is 40 (47).

For each patient aged between 8 and 14 years, the provided benefit was amplified through the questionnaire of self-evaluation elaborated by Boscolo et al. (2006) (Annex 3). This instrument contain closed questions, which are accompanied of illustrative engravings referring to the benefit provided by the hearing aids in the residential environment, at school and social living. This questionnaire was responded by the patient itself, but in a few cases, like when the patient did not understood the engraving, or was necessary to pass some complementary information by means of Sign Language or indicative gestures, the help from the family or responsible was allowed (8).

Based on the stablished criteria, were evaluated 63 children and teenagers, and the IT-MAIS scale was applied in 1 individual, the scale MAIS in 10 individuals and the questionnaire of evaluation from the benefit in children

Annex I. Infant-toddler Meaningful Auditory Interaction Scale (IT- MAIS) (Zimmerman-Phillips, Osberger \& Robbins, I997 adaptado por Castiquini e Bevilacqua, 2000).

I. The vocal behavior of the child is modified when it is using the hearing aid?
() 0 never
( ) I rarely $(25 \%)$
( ) 2 occasionally (50\%)
( ) 3 frequently (75\%)
( ) 4 always ( $100 \%)$

2. The child produces well articulated syllables and syllabic sequences that may be recognized as speaking?
( ) 0 never
( ) I rarely $(25 \%)$
( ) 2 occasionally (50\%)
( ) 3 frequently $(75 \%)$
( ) 4 always (100\%)

3. The children respond spontaneously to his name, in a quietenvironment, when called only through hearing via, without visual clues?
() 0 never
( ) I rarely (25\%)
( ) 2 occasionally (50\%)
( ) 3 frequently (75\%)
( ) 4 always (100\%)

4. . The child respond spontaneously to his name, in the presence of background noise, when called only through hearing via, without visual clues?
() 0 never
( ) I rarely $(25 \%)$
( ) 2 occasionally (50\%)
( ) 3 frequently $(75 \%)$
( ) 4 always (100\%)

5. The children, spontaneously, is attentive to the environmental sound (dogs,toys) without being induced or alerted earlier aboutthem?
() 0 never
( ) I rarely (25\%)
( ) 2 occasionally (50\%)
( ) 3 frequently (75\%)
( ) 4 always ( $100 \%)$

6. The child is alert, spontaneously, to the hearing signals when in new environments?
() 0 never
( ) I rarely $(25 \%)$
( ) 2 occasionally (50\%)
( ) 3 frequently $(75 \%)$
( ) 4 always ( $100 \%)$

7. The child recognizes, spontaneously, the hearing signals that make part of the daily routine?
() 0 never
( ) I rarely $(25 \%)$
( ) 2 occasionally (50\%)
( ) 3 frequently $(75 \%)$
( ) 4 always (100\%)

8. The child shows abilities to discriminate spontaneously two speakers, using only the hearing, withou visual clues?
( ) 0 never
( ) I rarely $(25 \%)$
( ) 2 occasionally (50\%)
( ) 3 frequently $(75 \%)$
() 4 always ( $100 \%)$

9. The child notice, spontaneously, the diferences between the sounds of speek and not speek through only the hearing?
( ) 0 never
( ) I rarely $(25 \%)$
( ) 2 occasionally (50\%)
() 3 frequently $(75 \%)$
( ) 4 always (100\%)

10. The child associates, spontaneously, the entonation from the voice (anger, excitement) and the meaning only through hearing?

() 0 never () I rarely (25\%) () 2 occasionally (50\%) $\quad$ () 3 frequently (75\%) () 4 always ( 100\%)

Total of points: $\quad / 40$ Scale IT-MAIS: $\quad \%$


Annex 2. Meaningful Auditory Interaction Scale (MAIS) (Robbins; Renshaw; Berry, 199I adapted by Castiquini e Bevilacqua, 2000).

I. The child recquires that put his hearing aid or put himself?
() 0 never
() I rarely
() 2 occasionaly
() 3 frequently
() 4 always

2. The child reports and seems to be disturbed when his hearing aid is not working for some reason?
( ) 0 never
() I rarely
() 2 occasionaly
() 3 frequently
() 4 always

3. The child answer spontaneously to his name, when is silence when called, without visual clues?
( ) 0 never
() I rarely
( ) 2 occasionaly
() 3 frequently
() 4 always

4. The child answer spontaneously to his name, when in the presence of environmental noise when called, without visual clues? How manytimes itanwers in the first try?
() 0 never
() I rarely
( ) 2 occasionaly
() 3 frequently
() 4 always

5. The child is alert, spontaneously to the hearing signals when in new environments?
( ) 0 never
() I rarely
() 2 occasionaly
() 3 frequently
( ) 4 always

6. The child is alert, spontaneously to the hearingsignals when in new environments?
( ) 0 never
() I rarely
() 2 occasionaly
( ) 3 frequently
() 4 always

7. The child recognizes, spontaneously, the hearing signals that make parto fthe domestic and scholar routine?
( ) 0 never
() I rarely
( ) 2 occasionaly
() 3 frequently () 4 always

8. The child shows abilities to discriminate spontaneously two speakers, using only the hearing?
() 0 never
() I rarely
() 2 occasionaly
() 3 frequently
() 4 always

9. The child notice, spontaneously, the difference betweem the sounds of speech and enviromental only hearing?
( ) 0 never
() I rarely () 2 occasionaly
() 3 frequently
() 4 always

10. The child associates, spontaneously, the entonation of voice and the meaning only through hearing?

$\begin{array}{llll}\text { () } 0 \text { never () I rarely () } 2 \text { occasionaly } & \text { () } 3 \text { frequently } & \text { () } 4 \text { always }\end{array}$

Total of points: _ $\quad 140$ Scale MAIS: _ _ \%

and teenagers was applied in 52 individuals. All individuals were submitted to the application of the IT-MAIS and MAIS scales, had neurosensory hearing loss of a bilateral profound degree, with exception of one individual, which had neurosensory hearing loss of severe degree in the right ear and of profound degree in the left ear. But the individuals which were applied the questionnaire of evaluation of benefit in children and teenagers, had others types and degrees of hearing losses, since that the authors from the questionnaire did not make references to the limitation of its application in many configurations of hearing losses. To facilitate the visualization from the data, in Image 1, are exposed the types and degrees of hearing losses, from the 52 individuals that responded to the questionnaire of evaluation from the benefit in children and teenagers (8).

The obtained data from the evaluations were analyzed and presented descriptively.

\section{RESULTS}

Only in $1(1,6 \%)$ individual was applied the scale of Infant-toddler Meaningful Auditory Integration (IT-MAIS), because this was the only patient that fit the age group of application of the instrument of self-evaluation. The score found in this case was equal to zero.

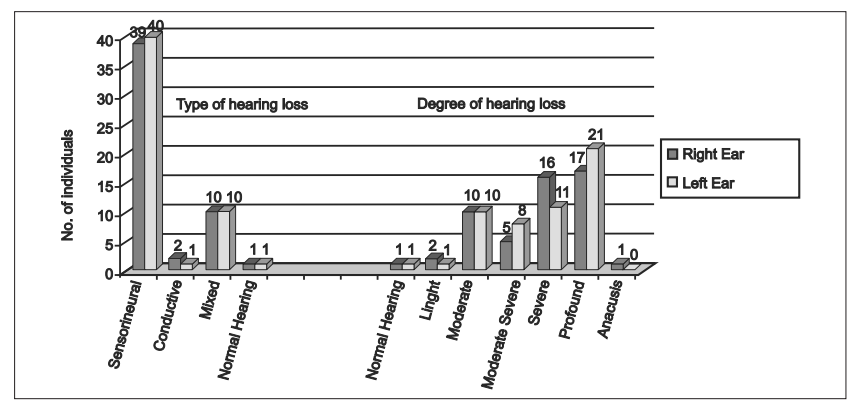

Image 1. Distribution from the individuals according to the type and degree from the hearing loss by ear $(n=52)$.

Regarding the Meaningful Auditory Integration Scale (MAIS), this could be applied in 10 (15,9\%) individuals, all carriers of neurosensory hearing loss of profound bilateral degree, with exception of one individual, which had hearing loss of severe degree in the right ear and profound degree in the left ear.

In Table 1 were found the score and the rates reached for each individual, in the MAIS scale. Still in this table, are found data referring to the regular use and the time of adaptation of the hearing aid.

Regarding the time of adaptation to the hearing aids in these individuals, were found very different values and 
Annex 3. Questionnaire of Evaluation from Benefit of HA in Children and Teenagers (BOsCOLO et al., 2006).

Name:

Age:

Series:

Which ear uses the HA:( )RE ( )LE ( ) Both

Use from HA:

( ) Only at home

( ) Only at school

( ) Only in therapy with the phono

( ) At home and in therapy

( ) At home and at school

( ) In all the places i go

I use the HA:

( ) Only by the morning

( ) Only by the afternoon

( ) Only at the night

() for two periods (

( ) All day. I only take it out to shower or sleep

Part A: At home

I) The HA makes me to listen better to the TV?

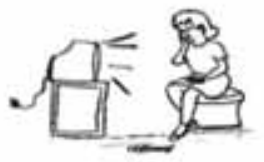
( ) Yes $;$
( ) No :
( ) A little $\odot$

2) With the HA i hear better the phone or the bell ringing?

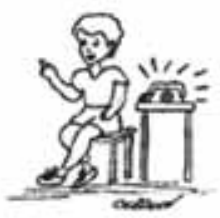
( ) Yes $: ;$
( ) No $:$
( ) A little $\odot$

3) With the HA i hear when my parentes call me?

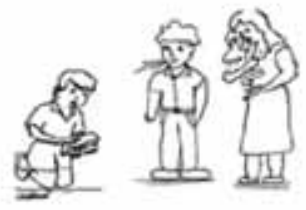
( ) Yes $:$;
( ) No :
( ) A little $\odot$

Part B: At school

I) With the HAi hear the professor better?

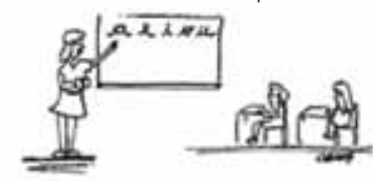

( ) Yes $:-\quad$ ( ) No $: \quad$ ( ) A little $:$
2) With the HA i listen my friends at class?

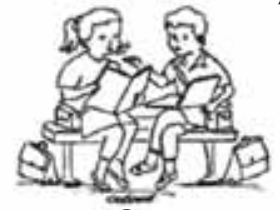
( ) Yes $\odot$
( ) No :
( ) A little $\odot$

3) With the HA i hear the professor when he is close?

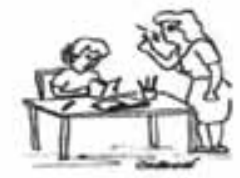
( ) Yes (;)
( ) No :
( ) A little $\odot$

4) With the HA i hear the professor when he is far?

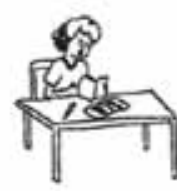

( ) Yes :)

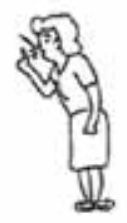

( ) No $:$

( ) A little $\odot$
Part C: Social

I) With the HA i play better with my friends?

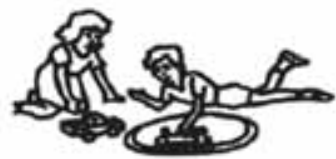
( ) Yes $\odot$
( ) No :
( ) A little $\odot$

2) With HAi hear my friends?

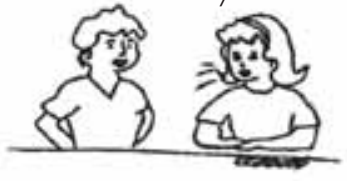
( ) Yes $:$
( ) No :
( ) A little $:$

3) With the HA i hear the cars going through the street?

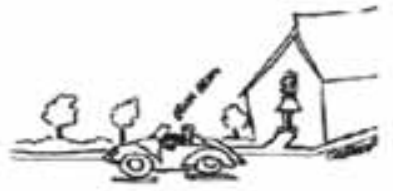
( ) Yes $\odot$
( ) No :
( ) A little $\odot$

4) With the HA i hear a person in a noisy place?

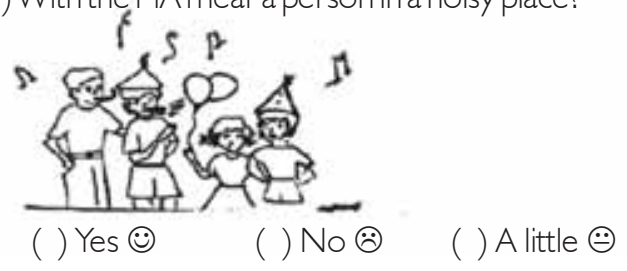


a few reliable, because the family did not know refer exactly how long the child used the hearing aid, in patients with fitting was not performed in our service. The minimum and maximum time approximated to the adaptation found in three months, and from 10 years, respectively.

Regarding the data referring to the responses found in the application of the questionnaire of evaluation from the benefits from HA in children and teenagers (8), is observed in Image 2, the analysis of the frequency of use from the hearing aids by the children and teenagers considering different environment.
In Image 3 is checked the distribution from the individuals regarding the responses about the benefit provided by the hearing aids referred by the children and teenagers in situations lived in the domestic environment; in Image 4, the ones lived in the school environment and in Image 5, the ones lived in a social environment.

\section{DISCUSSION}

Regarding the results found in the application of the IT-MAIS scale, only 1 (1,6\%) individual could be evaluated,

Table I. Score and individuals rates found in the MAIS scale, regularity from use and time of adaptation from the hearing aids in the evaluated individuals $(n=10)$.

\begin{tabular}{lcccc}
\hline Individuals & Score & Rate $(\%)$ & Regular use & Time of adaptation \\
\hline 1 & 4 & 10 & Yes & 6 months \\
2 & 3 & 7,5 & No & 10 months \\
3 & 15 & 37,5 & Yes & 1 I months \\
4 & 33 & 85 & Yes & I year and 6 months \\
5 & 8 & 20 & No & 8 months \\
6 & 18 & 42,5 & Yes & 2 years and 3 months \\
7 & 37 & 82,5 & Yes & I year and 9 months \\
8 & 23 & 57,5 & Yes & 4 years and 2 months \\
9 & 34 & 80 & Yes & | year and 2 months \\
10 & 24 & 60 & Yes & I year and 6 months \\
\hline Average & 19,9 & 48,2 & - & 18,3 months \\
\hline
\end{tabular}

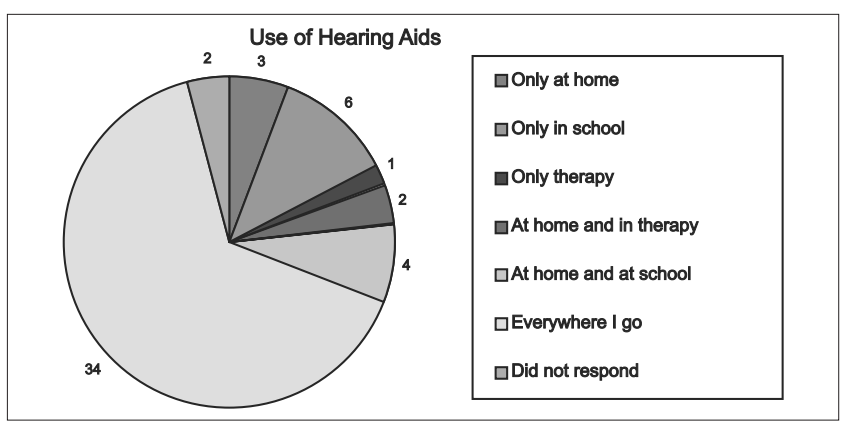

Image 2. Distribution from the individuals according the frequency of use of the hearing aids considering diferentes environments $(n=52)$.

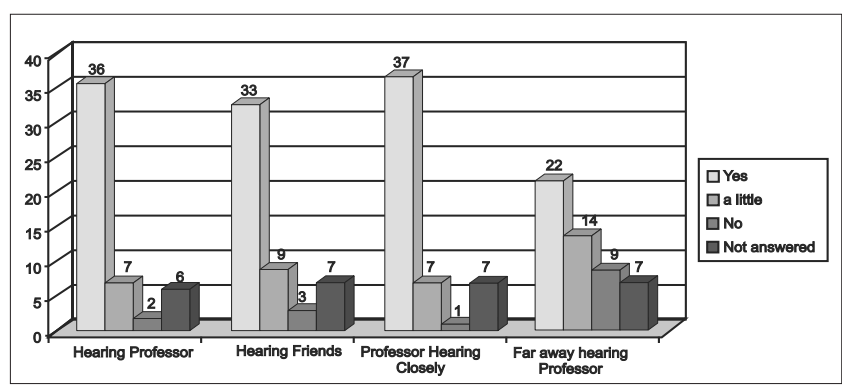

Image 4. Distribution from the individuals regarding the responses about the benefits provided by the hearing aids in a scholar environment $(n=52)$.

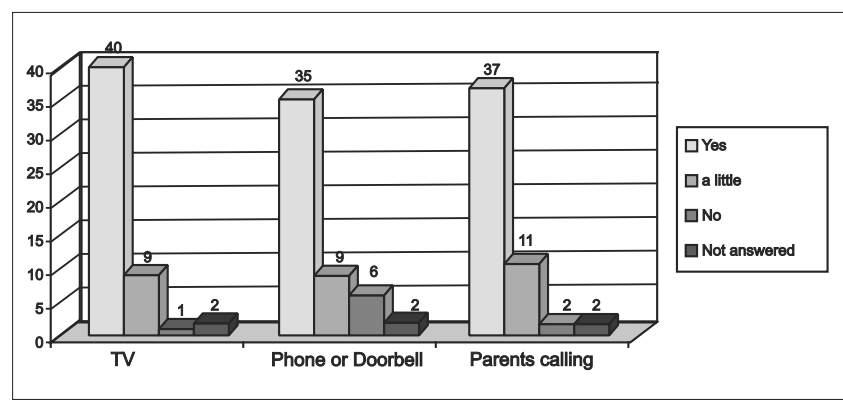

Image 3. Distribution from the individuals regarding the responses about the benefits provided by the hearing aids in the domestic environment $(n=52)$.

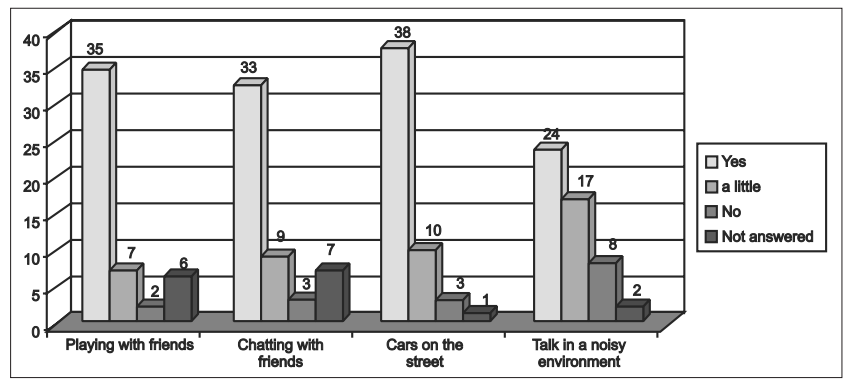

Image 5. Distribution from the individuals regarding the responses about the benefits provided by the hearing aids in a social environment $(n=52)$. 
because it was the only patient that fit in the age group of application from this instrument of self-evaluation. The score found in this case was equal to 0 (zero), in other words, the family referred that the child did not presented, in any moment, none of the behaviors evaluated in the scale, even using the hearing aid. But, this patient besides of hearing impairment of a profound degree, a chart of many neuropsychomotor limitations resulting from cerebral paralysis, not presenting the head control, which compromised the analysis from the development from the hearing aids.

As the results found in the application of the scale MAIS have showed very different, and the minimum rate found was of $7,5 \%$ and the maximum $85 \%$, obtaining an average rate of $48,2 \%$ in the group of individuals evaluated.

In literature are found values varied in the application of this scale. Were found approximated values, and the results of this study were better than the ones reported by other studies that obtained average rates of $25,42 \%$ and $22,6 \%$ when evaluating 12 individuals carriers from hearing impairment from severe and profound degree, users from hearing aids $(3,11)$. Also, were found in the literature values lower than the one found in this study $(4,12)$, such researches refer to an average rate of $70 \%$ when applied the scale with the family of 10 children carriers from neurosensory hearing loss of profound bilateral degree, users of hearing aids and, rates above $82,5 \%$ in 20 children carriers of malformation from the external and middle ear, carriers of conductive hearing loss of a moderate degree and users of devices of hearing aids by bone conducting.

From the group of 10 children analyzed, could be observed that all the researched individuals had neurosensory hearing loss of bilateral profound degree, with exception of the individual number 7 , which had hearing loss of a severe degree in the right ear and profound degree in the left ear, and this was the one that had the second best performance among the evaluated individuals $(82,5 \%)$. Is referred by other authors, that the found rate in the scale increases proportionally, according to the hearing capacity of the child, and so the amount of residual hearing influences directly on the result found (7).

The patients 5 and 9 , besides the hearing impairment, had neuropsychomotor limitations resulting from cerebral paralysis. Besides, is observed that the individual number 5 did not make effective use of the hearing aid, which can justify the poor performance found (20\%). In other hand, the individual number 9 , even having limitations resulting from cerebral paralysis, obtained a performance extremely satisfactory in the evaluated behaviors (80\%).

Analyzing the Table 1 , is observed that the individuals 1,3 and 6 had a satisfactory performance, in other words, a rate lower than 50\% (7), even using regularly the hearing aid and did not having changes that would influence directly in the hearing capacity. However, must take to account that the scale is scored from information provided by the family of the child, in this way, the feelings regarding the hearing impairment and the use of the hearing aid can have certain influence in the obtained answers (13).

The result obtained by means of application from the MAIS scale to the family provided important information regarding the hearing spontaneous behavior of the children in situations of daily life. Such information could not be obtained by standard battery of tests, once that these behaviors tend to occur at home and not in testing environment, which have control from the environment sound (14). Therefore, the results obtained in the MAIS scale serve to contribute for the evaluation of perception of speech, complementing the objective procedures (7).

And so the obtained results with the MAIS scale, the results obtained through the application of the questionnaire of evaluation from the benefits in children and teenagers (8) were very important, most of all because evaluated the benefit provided by the sound amplification through information from the patient itself.

Because it is a questionnaire with questions of easy access and for having the help of illustrative engravings, itself was responded without difficulties by most of the patients.

As well as the one found by the author of the questionnaire (8), the individuals presented biggerdifficulties from utterance interpretation of the questions by the children and teenagers with hearing loss of profound degree. Because the absence of oral/auditory experiences, this individuals have difficulties in the access of the written language and favor more than one system of visual-spatial language $(15,16)$. So, with the help of the engravings and of signs language or indicative gestures, the meaning from the wording of the questions was easily reached (17).

Regarding the use of the hearing aid could be observed that $34(65,4 \%)$ individuals said to use the prosthesis everywhere they go, taking off only to shower or to sleep. This data reveals the interest and commitment with the use of the hearing aid, because of the benefits that it has to offer to those individuals (8).

But other individuals, said to use the prosthesis in more specifically environments, in other words, $3(5,7 \%)$ only at home, $6(11,5 \%)$ only at school, 1 only in therapy $(1,9 \%), 2$ at home and in therapy $(3,8 \%)$ and $4(7,6 \%)$ at home and at school. It is observed that certain patients choose to use the hearing aid only in situations which the 
communicative demands increase, being that it some cases, the restrict use of the hearing aid was usually related to resistance from the patient and not from a bad adequation to the standards of amplification from the prostheses. In these cases it becomes necessary to guide the responsible and the hearing impaired itself about the benefits that the hearing aid can provide (8).

It is known that the benefits from the hearing aids it is related to the improvement from communication in daily life, including the reduction from the inability and from hearing disadvantage (18). In this context, is included the domestic environment, because it is in this environment that occurs great part of the daily events, besides being the environment that has all the family living. And so, regarding the benefit provided by the hearing aids in the situation of routine, lived in a domestic environment, was checked that $40(76,9 \%)$ patients said that the hearing aid helps to hear better the television, $35(67,3 \%)$ to hear better the phone ringing or the bell and $37(71,1 \%)$ to hear the parents calling their names, agreeing with the results founds for other studies (8).

Regarding the benefit provided by the hearing aids in a school environment, was said by $36(69,2 \%)$ children and teenagers that the hearing aid helps to hear the professor better, $33(63,5 \%)$ said that helps to hear their classmates better. The biggest difficulty found was to listen the teacher when he is far $22(42,3 \%)$. This reinforces the need to be guided as the positioning from the student next to the teacher, because it favors the perception from the signal of the speech and reduces the interference from the environmental noise (19).

When analyzing the benefit provided by the hearing aids in situations of routine lived in a social environment, we found satisfactory results. Was observed that 35 children and teenagers $(67,3 \%)$ reported that with the hearing aid they play better with their friends, $33(63,4 \%)$, listen to the friends talking, $38(73,1 \%)$, are able to hear cars passing through the street, and $24(46,1 \%)$ said that they can hear a person talking in a very noisy local. It is observed that by means of the results, the use of the hearing aid is indispensable for the maintenance of the social living from children and teenagers that were evaluated, helping in the improvement of life for them (20).

Was observed that only 24 individuals $(46,1 \%)$ said to hear better when a person is talking in a noisy local. Authors referred that in an noisy environment, the individual can present numerous difficulties in the intelligibility of speech, because the number of lanes falls significantly, taking them to use only available lanes on the situation. In those environments, is necessary that the standards of amplification from the hearing aid are well adjusted to do not cause any hearing discomfort, which can lead the user to a withdrawal from the use of the prostheses in these situations $(8,21)$.

The success of adaptation from the hearing aids depends from the analysis of the benefit that the prostheses provides for each user and this measures are each time more importante in any program of adaptation of hearing aids (22).

The execution of this study allow us to suggest the use of the questionnaire of evaluation from the benefit in children and teenagers (8), with the purpose of evaluate the benefit provided by the amplification about the point of view from the patient, since this instrument has showed to be effective into providing information about the benefit that the hearing aid provides in situations of domestic routine, scholar and social for children and teenagers evaluated.

\section{CONCLUSION}

From the analysis and discussion from the obtained results, was verified that in the application of the MAIS scale were found satisfactory rates (above 50\%) and 5 (50\%) from the tem evaluated individuals.

In the application of the questionnaire of evaluation from the benefit in children and teenagers (8), was checked that all items evaluated the most of the children and teenagers said to be having an improvement in the performance because of the use of the hearing aid.

So, was checked benefit provided by the sound amplification, in different situations of the daily life, as for the view of the patient as for his family view. In a few cases, where it was found a little or none benefit with the use from the amplification, there was influence from clinical alterations, besides the hearing losses, influencing in the effective use from the hearing aids.

\section{BiBLIOGRAPHIC REFERENCES}

1. Vieira ABC, Macedo LR, Gonçalves DU. O diagnóstico da perda auditiva na infância. J Pediatr. 2007, 29(1):43-49.

2. Almeida RP, Amaral LCG. Programa de doação de prótese auditiva: avaliação do ano de 2004. Rev Bras Promoç Saúde. 2007, 20(2):99-103.

3. Couto MIV, Lichtig I. Efeitos da amplificação sonora sobre as modalidades comunicativas utilizadas pelos pais. PróFono. 2007, 19(1):75-86. 
4. Robbins AM, Renshaw JJ, Berry SW. Evaluating Meaningful Auditory Integration in Profoundly Hearing-impaired children. Am J Otol. 1991, 12(supplement).

5. Zimmerman-Phillips S, Osberger MJ, Robbins AM. InfantToddler: Meaningful Auditory Integration Scale (IT-MAIS). Sylmar, Advanced Bionics Corporation, 1997.

6. Castiquini EAT, Bevilacqua MC. Avaliação da percepção da fala em crianças deficientes auditivas profundas. In: XIII Encontro Internacional de Audiologia, 1998, Bauru. Anais do XIII Encontro Internacional de Audiologia, 1998. p. 81.

7. Castiquini EAT, Bevilacqua MC. Escala de integração auditiva significativa: procedimento adaptado para a avaliação da percepção da fala. Rev Soc Bras Fonoaudiol. 2000, 4(6):51-60.

8. BoscoloCC etal. Avaliação dos benefícios proporcionados pelo AASI em crianças e jovens da faixa etária de 7 a 14 anos. Rev Bras Educ Esp. 2006, 12(2):255-268.

9. Bess FH, Hedley-Williams A, Llichtenstein MJ. Avaliação auditiva em idosos In: Musiek FE, Rintelmann WF. Perspectivas atuais emavaliaçãoauditiva, São Paulo: Monole; 2001.p.343-364.

10. Weinstein BE. Treatment efficacy: hearing aids in the management of hearing loss in adults. J Speech Lang Hear Res. 1996, 39(5):37-45.

11. Couto MIV, Lichtig I. Amplificação e (re)habilitação: direitos e necessidades das crianças surdas. In: II Seminário ATIID, 2003, São Paulo. Anais do II Seminário ATIID, 2003.

12. Aringa AHBD, Castiquini EAT. Adaptação do Aparelho de Amplificação Sonora Individual por Via Óssea em Crianças Portadoras de Malformação de Orelha Externa e Média. Arq Int Otorrinolaringol. 2005, 9(2):310.

13. Boscolo CC, Santos TMM. A deficiência auditiva e a
Família: sentimentos e expectativas de um grupo de pais de crianças com deficiência da audição. Distúrb Comun. 2005, 17(1):69-75.

14. Osberger MJ et al. Use of a Parent-Report Scale to assess benefit in children given the Clarion Cochlear Implant. Am J Otol. 1997, 18(supplement):S79-80.

15. Harrison KMP, Lodi AC, Moura MC. Escolas e escolhas: o processo educacional dos surdos. In: Lopes Filho OC. Tratado de Fonoaudiologia. São Paulo: Roca, 1997, p. 360400 .

16. Bandini HHM, Oliveira CLAC, Souza EC. Habilidades de leitura de pré-escolares deficientes auditivos: Letramento Emergente. Paidéia. 2006, 16(33):51-58.

17. Cader FAAA, Fávero MH. A mediação semiótica no processo de alfabetização de surdos. Rev Bras Educ Esp. 2000, 6(1):117-131.

18. Almeida K. Avaliação dos resultados da intervenção. In: Almeida K, Iório MCM. Próteses auditivas: fundamentos teóricos e aplicações clínicas. $2^{\underline{a}}$ ed. São Paulo: Lovise; 2003. p.335-53.

19. Marriage JE et al. Effects of three amplification strategies on speech perception by children with severe and profound hearing loss. Ear Hear. 2005, 26(1):35-47.

20. Gil D. Treinamento auditivo formal em adultos com deficiência auditiva. [Tese de Doutorado] São Paulo: Universidade Federal de São Paulo. 2006, p. 181.

21. Caporali SA, Silva JA. Reconhecimento de fala no ruído em jovens e idosos com perda auditiva. Rev Bras Otorrinolaringol. 2004, 70(4):525-532.

22. Haskell GB et al. Subjective Measures of Hearing Aid Benefit in the NIDCD/VA Clinical Trial. Ear Hear. 2002, 23(4):301-307. 